\title{
The Lack of Knowledge on the Microbiome of Golf Turfgrasses Impedes the Development of Successful Microbial Products
}

\author{
Uli Stingl ${ }^{1, *}$, Chang Jae Choi ${ }^{1}$, Braham Dhillon ${ }^{2}$ and Marco Schiavon ${ }^{3}(\mathbb{D}$ \\ 1 UF/IFAS Fort Lauderdale Research and Education Center, Department of Microbiology \& Cell Science, \\ University of Florida, Davie, FL 33314, USA; changjae.choi@ufl.edu \\ 2 UF/IFAS Fort Lauderdale Research and Education Center, Department of Plant Pathology, University of \\ Florida, Davie, FL 33314, USA; dhillonb@ufl.edu \\ 3 UF/IFAS Fort Lauderdale Research and Education Center, Environmental Horticulture Department, \\ University of Florida, Davie, FL 33314, USA; marcoschiavon@ufl.edu \\ * Correspondence: ustingl@ufl.edu
}

Citation: Stingl, U.; Choi, C.J.; Dhillon, B.; Schiavon, M. The Lack of Knowledge on the Microbiome of Golf Turfgrasses Impedes the Development of Successful Microbial Products. Agronomy 2022, 12, 71. https://doi.org/10.3390/ agronomy12010071

Academic Editor: Fenliang Fan

Received: 3 December 2021

Accepted: 27 December 2021

Published: 29 December 2021

Publisher's Note: MDPI stays neutral with regard to jurisdictional claims in published maps and institutional affiliations.

Copyright: (C) 2021 by the authors. Licensee MDPI, Basel, Switzerland. This article is an open access article distributed under the terms and conditions of the Creative Commons Attribution (CC BY) license (https:// creativecommons.org/licenses/by/ $4.0 /)$.

\begin{abstract}
Golf courses have a significant environmental impact. High water demands and the intensive use of agricultural chemicals have been a concern for decades and are therefore in the focus of efforts to make golf courses more environmentally sustainable. Products based on modifying or using plant-associated microbiota are one of the fastest-growing sectors in agriculture, but their application on turfgrasses on golf courses is so far negligible. In this review, we summarize the limited knowledge on microbiomes of golf turf ecosystems and show that the lack of holistic studies addressing the structure and function of golf turf microbiomes, including their responses to intense turf management procedures, is currently the main bottleneck for development and improvement of reliable, well-functioning microbial products. We further highlight the endosphere of turfgrasses, which is easily accessible for microbial cultivation through constant mowing, as the most stable and protected micro-environment. Many grass species do possess endophytic bacteria and fungi that have been shown to improve the plants' resistance towards microbial pathogens and insect pests, and several products using endophyte-enhanced grass varieties are commercially successful. We anticipated that this trend would tee-off on golf courses, too, once a more comprehensive understanding of golf turf microbiomes is available.
\end{abstract}

Keywords: microbiome; golf turf; turfgrasses; biocontrol; microbial communities; endophytes

\section{Economic, Social, and Ecological Importance of Golf Courses}

Turfgrass areas including lawns, parks, sports fields, and golf courses, support numerous industries that generate over 58 billion USD and cover more than 62 million acres in the US alone [1,2]. Golf, in particular, is an enormously popular sport that is being enjoyed by more than 61 million people worldwide, with the majority of the players being in the US [3]. The 15,204 golf facilities in the US cover around 2.3 million acres [4] and undoubtedly provide enormous social, recreational, and economic benefits [5] (and quite some frustration at times, to be honest). While the number of golf courses in the US has stayed relatively stable in the last two decades [3,4], globally, it increased between 2005 and 2010 by around $15 \%$ [6] and is continuously growing.

\section{Environmental Impacts of Golf}

In order to maintain healthy, good-looking, and playable golf surfaces, intense turfgrass management is necessary and unavoidable. Therefore, golf courses usually have a significant impact on the environment, including high water usage and consequences of the application of large amounts of agricultural chemicals. The US Golf Association (USGA) had realized these environmental impacts in the 1980s and has since been working on ameliorating the environmental impact of golf by conducting and sponsoring research 
on environmental issues related to golf. The USGA Environmental Research Program was established in 1991 with the main objectives to (1) understand the effects of turfgrass pest management and fertilization on water quality, (2) evaluate valid alternative pest control methods, and (3) document the benefits of turfgrass and golf courses to humans, wildlife, and the environment [7].

The annual water usage on a golf course in the US varies a lot by geographical region but averages around 52,000 $\mathrm{m}^{3}$ [8], or around 14 million gallons per course, accounting for roughly 200 billion gallons in the whole US. Although these estimates are hardly accurate and too simplistic to be used for reliable national or global estimates [9], they certainly demonstrate the magnitude of water usage by the golf industry. Drought-tolerant turfgrass species and cultivars [10-13] increased irrigation efficiency [14], the use of wetting agents [15], as well as the use of impaired water sources and rainwater harvesting [16], have significantly reduced the water footprint of golf courses over the last decades.

In a similar manner, more environmentally friendly organic fertilizer and compost are increasingly being used to reduce and replace some inorganic fertilizers [3]. Many golf courses now also have constructed wetlands that act as a habitat for diverse animal and plant species, but also provide a buffer system where toxic chemicals can be biologically degraded before entering the groundwater [3]. Despite significant progress in making golf courses 'greener' [17], there are still considerable doubts about the (environmental) safety of certain chemicals on golf courses $[18,19]$.

A typical 18-hole course uses 22,680 kg of dry and liquid chemicals annually, which is several times more than the amount needed to grow an average crop [3]. While the majority of these chemicals are inorganic fertilizers, which are also of environmental concern as they sometimes cause groundwater quality degradation and ultimately eutrophication in connected waterways [20], there is also around $750 \mathrm{~kg}$ of pesticides that are sprayed or applied on a given course per year [21] to control numerous microbial diseases, insect pests, and damage by nematodes. In the European Union, the general use of pesticides on golf courses is banned and requires special approvals that are granted on a case-by-case basis [22]. Although biocontrol methods, either through stimulation of existing microorganisms or through adding novel organisms to the damaged course areas, have been explored and show promising results, their general application as a common best management practice on golf courses has been hampered by unsatisfactory and sometimes irreproducible results compared to well-established chemical pest control [7,23]. In this review, we want to highlight the lack of a general understanding of structure and function of the microbiome of turfgrasses and especially in golf turf, which is a pivotal factor in developing commercially successful methods that are based on modifying the turf microbiome. We firmly believe that a better understanding of structure and function of the microbiota in turfgrass ecosystems can lead to much improved microbial products that have the potential to replace some and to reduce the general usage of chemicals on golf courses and might provide other benefits that have not been explored yet, including reducing water usage.

Since 2003, studies related to 'microbiomes' have exploded in the peer-reviewed literature [24]. While this explosion is mostly due to work on human microbiomes, studies on agriculturally relevant microbiomes are also on the rise. Agricultural products based on the microbiota are one of the fastest-growing sectors in agronomy with a Compound Annual Growth Rate (CAGR) of 15-18\% and a predicted value of over 10 billion USD by 2025 [25].

\section{Plant-Microbe Interactions}

Plant-microbe interactions have been extensively studied for more than a century (e.g., Beijerinck's work in the late 19th century on $\mathrm{N}_{2}$ fixation in legumes) leaving hardly any doubt that plants (as well as animals) and their associated microbial communities form interdependent functional entities, so-called holobionts [26-29]. Well-documented beneficial functions of plant-associated microorganisms include improved nutrient uptake, increased tolerance to different types of abiotic stress factors, and better resistance to 
pathogens, among others [30], but vary significantly based on host species and biotic as well as abiotic factors in the environment. The term 'microbiome' itself was introduced in 1988 , but until recently, it lacked a clear and common definition, mostly due to exponential progress in method development that allowed for more sophisticated studies that constantly changed our understanding of the complexity of microbial communities associated with higher organisms [31]. The currently most widely accepted definition of the 'microbiome' includes both the 'microbiota' (community of microorganisms) and the 'theater of activity' (structural elements, metabolites/signal molecules, and the surrounding environmental conditions) [31] to illustrate that the activity of the microbes does depend on the (micro-)environment.

In general, bacteria and fungi dominate plant-associated microbiota, although nematodes, protists, algae, and archaea can also play important roles [30,31]. Under the microbiota of plants, we define the sum of all microbial communities that directly affect the physiology of the plant host. These communities include microorganisms on leaves (phyllosphere), on roots, and the immediately surrounding soil (rhizosphere), as well as in the tissue of the plant (endosphere). Endospheric microorganisms might be either restricted to roots or leaves or be present in both, dependent on the host species and the microorganism. Varying physicochemical parameters and plant physiology (including plant exudates) select for specific microbial communities in these niches, resulting in distinctive and less diverse communities than in the surrounding soil. Concomitantly, the activity of plant-associated microbes is usually significantly higher than the activity of those in the surrounding soil [30].

Molecular methods using high-throughput sequencing of nucleic acids have revolutionized microbial ecology and allowed for sophisticated studies of all kinds of environmental and host-associated microbiomes in the last decades [32]. The most commonly used techniques to study microbiomes include sequencing methods based on analysis of phylogenetic marker genes (16S rRNA gene for bacteria and archaea, 18S rRNA gene,, and ITS for microbial eukaryotes) that can decipher community composition, metagenomic sequencing (sequencing of the total DNA of an environment) that can detect metabolic capacities of whole communities, and metatranscriptomics sequencing (sequencing of the total RNA of an environment) that can unravel which metabolic pathways are actively expressed [33].

\section{Lack of Comprehensive Data on the Microbiome of Golf Turfgrasses}

Microbiomes of many plants, including model organisms like Arabidopsis thaliana or important crops like rice, have been studied in great detail $[34,35]$, but holistic, stateof-the-art research on microbial communities associated with turfgrasses, especially those used on golf courses, are lagging far behind (Figure 1). The lack of knowledge is even deeper as implied by the figure, considering that golf turfgrasses are highly diverse and include a multitude of different species and cultivars. Bermudagrass (Cynodon spp.) makes up 34\% of all US golf acreage, followed by Kentucky bluegrass (Poa pratensis L., 23\%) and annual bluegrass (P. annua L., 11\%), but there are many more species that are being used for golf courses in different geographical regions, or even for different playing surfaces (tees, fairways, greens, and roughs) on the same course [4].

While Figure 1 certainly greatly underestimates the number of papers on microbes in turfgrass systems, mostly due to the use of very specific keywords in the title/abstract/ keywords and the fact that the term 'microbiome' was only coined in 1988, it clearly illustrates a real lack of holistic studies targeting microbiomes in golf turf. Most microbiological work on golf courses has focused on identifying pathogens, as a response to the vast damage that they cause [1]. 


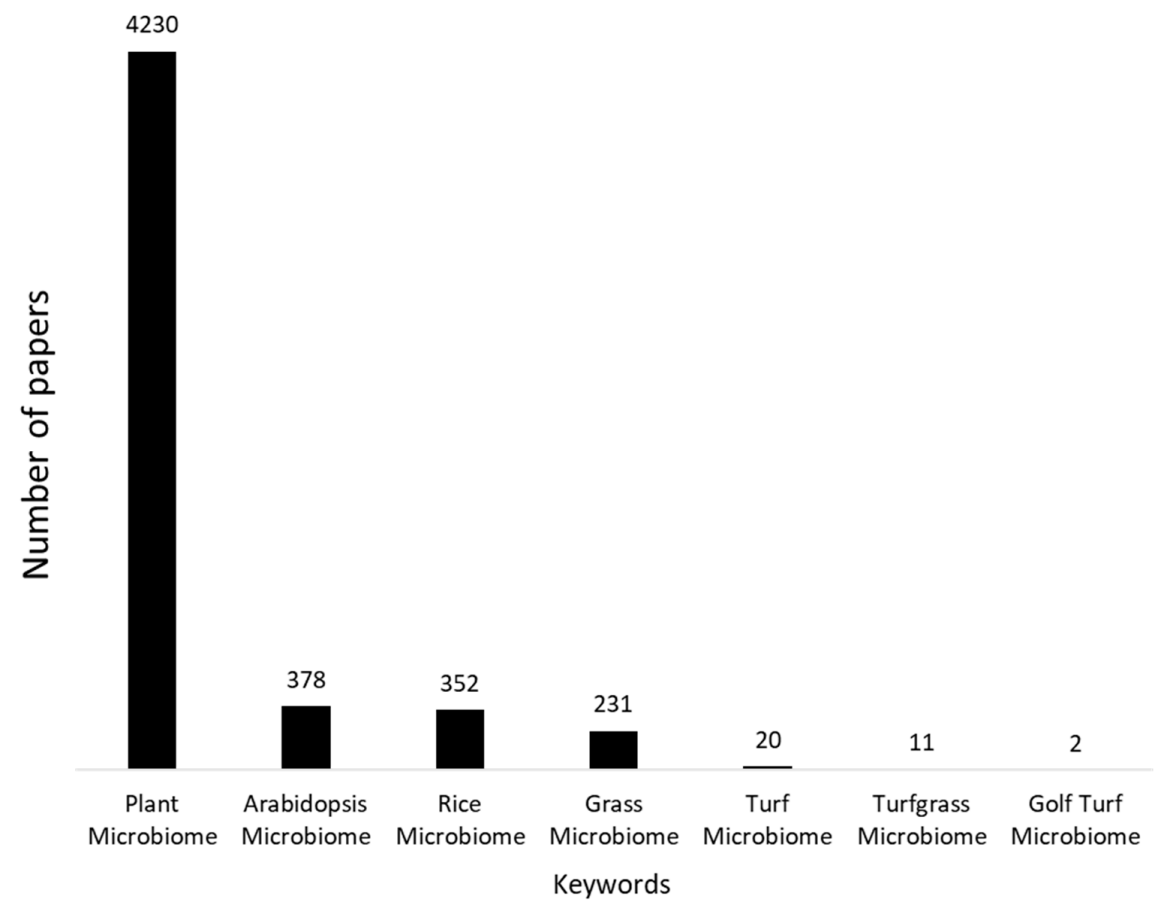

Figure 1. Numbers of papers related to specific keywords in the Web of Science Core Collection, illustrate the lack of knowledge on golf turf microbiomes.

Comprehensive studies using state-of-the-art methodologies in microbial ecology are (so far) rare in golf turf ecosystems. Xia et al. [36] used marker gene analyses to investigate bacteria and fungi in roots and rhizosphere of four golf turfgrass species (creeping bentgrass [Agrostis stolonifera L.], bermudagrass, and ultradwarf bermudagrass) in North Carolina and demonstrated distinct microbiota in these microhabitats, also compared to bulk soil; the turfgrass species had little impact on microbial community composition in this study. The rhizosphere communities were more similar to those in bulk soil, and the root endosphere microbiota was clearly distinct. The bacterial species Pseudomonas veronii and Janithobactererium lividum, as well as the fungal genus Pseudogymnoascus, were identified as the most abundant groups associated with plant tissue although phyllosphere organisms were not analyzed in this study. While close relatives of these microbial species have been associated with plant-growth-promoting capacities, their function in turfgrass, as well as their distribution in other turfgrass species and/or other climate zones warrants further investigation.

Recent data from our labs corroborate some of these results but also hint at complex mechanisms that govern the assembly of microbial communities related to turfgrass. Figure 2 depicts a comparison of the microbiota of phyllosphere, endosphere, and rhizosphere microbiota of two cultivars of hybrid bermudagrass [Cynodon dactylon L. Pers. $X$ Cynodon transwaalensis (Burtt-Davy)] ('Latitude 36' and 'TifTuf', managed identically at fairway height), and St. Augustinegrass (Stenotaphrum secundatum [Walt.] Kuntze) managed by simulating typical homeowner care. Fungal communities (Figure 2a) showed more distinct separation between the different grasses than bacterial ones (Figure 2b), indicating that governing factors that shape these communities, including physico-chemical conditions (e.g., nutrient content, $\mathrm{pH}$, water content, redox state), but also potential host-mediated factors (e.g., exudates), might act differently on fungi and bacteria (and their subgroups). Main bacterial groups included Bacteroidetes, Proteobacteria, and Patescibacteria, while fungal communities were dominated by Dothideomycetes, Sordariomycetes, and Agaricomycetes (Choi et al., in prep), a community composition that differed significantly from the results of Xia et al. [36], which were retrieved from a different climate zone (North Carolina versus southern Florida), but also included bermudagrass samples. 
a

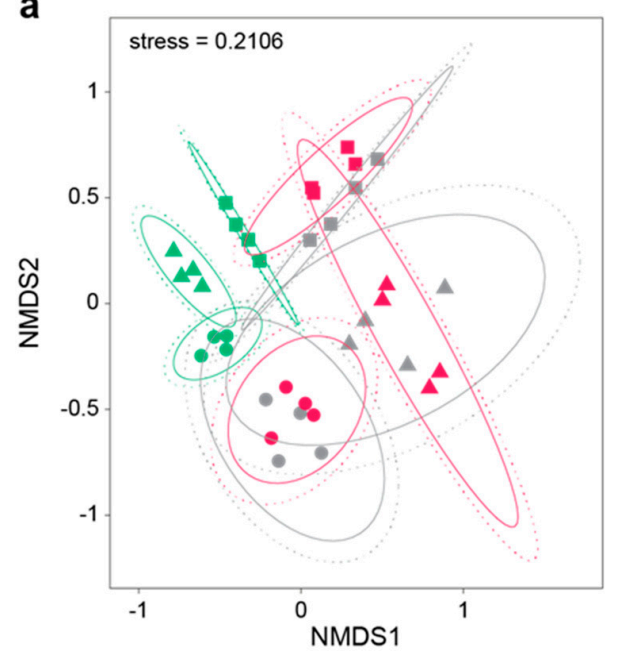

b

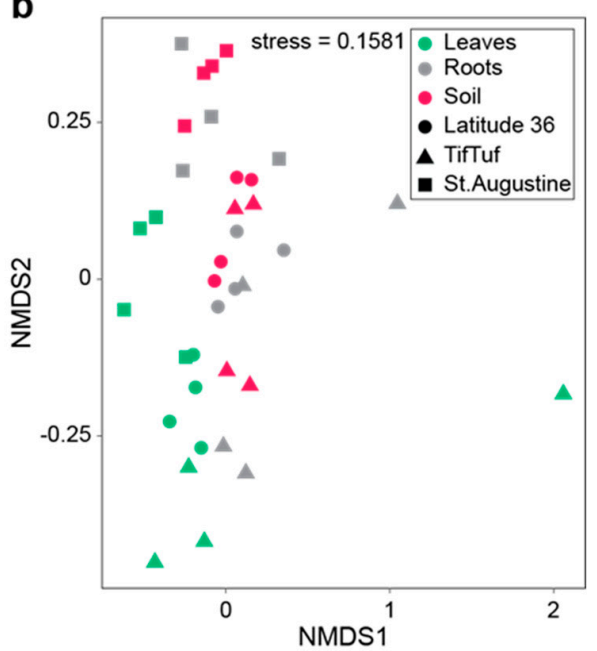

Figure 2. Non-metric multidimensional scaling plot of microbial communities ((a), fungi; (b), bacteria) associated with different microhabitats (colored) on two equally managed cultivars of bermudagrass (Latitude 36 and TifTuf), and an adjacent St. Augustinegrass managed by simulating typical homeowner care.

While there are only a few studies that systematically analyze plant-associated microbiota in golf turfgrass systems, several studies focus on soil bacteria in turfgrass systems. Allan-Parkins et al. [37] demonstrated that certain management practices do have an impact on fungal communities in the soils around different playing surfaces and less of an impact on bacterial communities; microbiota directly attached to the plant or in the endosphere were not studied. The authors could also show that the soil microbiota varied significantly in different playing surfaces, which could be a result of divergent management practices. Similarly, Bartlett et al. [38] studied soil microbial communities in different playing surfaces on golf courses in the UK. By using fatty acid profiles rather than sequencing of nucleic acids, the authors also found that communities clustered based on playing surfaces (tees, fairways, greens).

The impact of the host species on the soil microbiomes around turfgrasses has been discussed in several studies, although clear answers are still missing. Zhang and Yao [39] analyzed microbial communities in soils associated with two turfgrass species (Festuca elata Keng ex E.B.Alexeev, and perennial ryegrass [Lolium perenne L.]). Both fungal and bacterial populations showed significant differences between the two kinds of grass but also many overlapping organisms that were present in both. Xia et al. investigated the impact of host species and management practices on soil microbiota in turfgrass and showed that communities in putting greens differed from those in other playing surfaces and other habitats, and that defoliation management (= mowing height and frequency), not host species, was the main factor in shaping the soil microbiota, despite analyzing very diverse C3 cool-season and C4 warm-season species [40]. The work by Zhu et al. [41] implied significant impacts of seasons, turfgrass species, soil depth, and growing season on soil microbiota associated with turfgrass.

Recently, turfgrass seeds of diverse grass species were analyzed for associated microorganisms $[42,43]$. The authors documented differences in bacterial communities associated with climate [43], and the presence of diverse fungal pathogens on/in the seeds [42]. While many grass species and cultivars used for golf are hybrids and are usually grown vegetatively, overseeding a warm-season grass with a cool-season grass is common practice in the Southern US and in the transition zone, and pathogens, as well as beneficial microbes associated with the seeds, can potentially establish in or around the plants. Chen et al. [43] showed that the seeds of the three investigated grass species (red fescue [Festuca rubra L.], tall fescue [Lolium arundinacea (Schreb.) Darbysh.], and perennial ryegrass) had a core microbiome consisting of 27 genera from the phyla Actinobacteria, Bacteroidetes, Patescibacteria, 
and Proteobacteria. Another study, focused on analyzing spores of mycorrhizal fungi in turfgrass, reported the presence of 18 different species. Spore abundance and composition showed some seasonal patterns and strong variation correlating with environmental factors and turf management [44].

Despite the clear lack of studies that comprehensively address the microbial community structure of turfgrass-associated microorganisms under controlled conditions, it is evident that there are many different factors that potentially impact the structure and function of the turfgrass microbiome. A taxonomic core-microbiota, defined as a group of microbial species that are present in most microbiomes of the same plant species, has been illustrated for several plants including landmark papers on Arabidopsis thaliana [45,46], has not really emerged for golf turfgrasses and might not even exist. Rather than focusing on the search for common taxa, Lemanceau's recommendation that studies on plant-associated microbial communities should rather focus on common functions of the microbiota [47] seems appropriate for turfgrass. However, more detailed studies on the impact of different factors on the structure of microbial communities associated with diverse turfgrasses are necessary to make that case. For fungal communities at least, a cultivation approach indicated a potential core microbiome for Festuca rubra subsp. pruinosa [48].

Figure 3 displays the complexity of the system and illustrates our opinion on how different factors might impact turf microbiome structure and function. Intensive management of turfgrass, e.g., frequent mowing, irrigation, traffic, fertilization, or the application of herbicides, fungicides, or nematicides, as well as different biotic and abiotic factors will have direct and indirect effects on the structure and function of turfgrass microbiomes. Direct effects include the increase in the availability of nutrients or elimination of pests, while indirect effects change soil properties that will in turn alter microbial communities. Additionally, there are interactions between members of the microbiota that can affect the structure and function of the whole community. Adding a single species, a so-called hub taxon, to the phyllosphere of Arabidopsis thaliana was shown to change the structure and function of the complete microbiome [49]. Similarly, the addition of microbial species to the soil can not only change soil communities, but can also impact microbiota in the root endosphere, and to a lesser extent, in the leaf endosphere [50]. While none of these studies were done on golf turfgrass, similar mechanisms might apply. An interesting study analyzing turf of the Park Grass Experiment in the UK showed that fertilizing turfgrass can have significant effects on microbial community structure in the surrounding soil [51]. Similarly, studies on microbiomes of agriculturally relevant grass species show the impact of management practices on bacterial and fungal microbiomes [52-54], but unfortunately, similar studies on golf areas are lacking.

While there is little research available on interactions between different members of the microbiome of turfgrasses, or responses of microbiomes related to management practices, there is a large body of literature that demonstrates how soil properties change based on turfgrass treatments. Diera et al. [55] analyzed the impact of wetting agents and two additional plant growth regulators on microbial communities in the soil, with the result that most effects were short-lived; endophytic communities or other plantassociated microbiota was not studied. A detailed understanding of how biotic and abiotic factors impact turf microbiomes can identify key taxa (and key functions), help to predict microbiome responses to treatments, and modify best management practices, and will be pivotal to improve grass health by fostering a 'healthy microbiome'. 


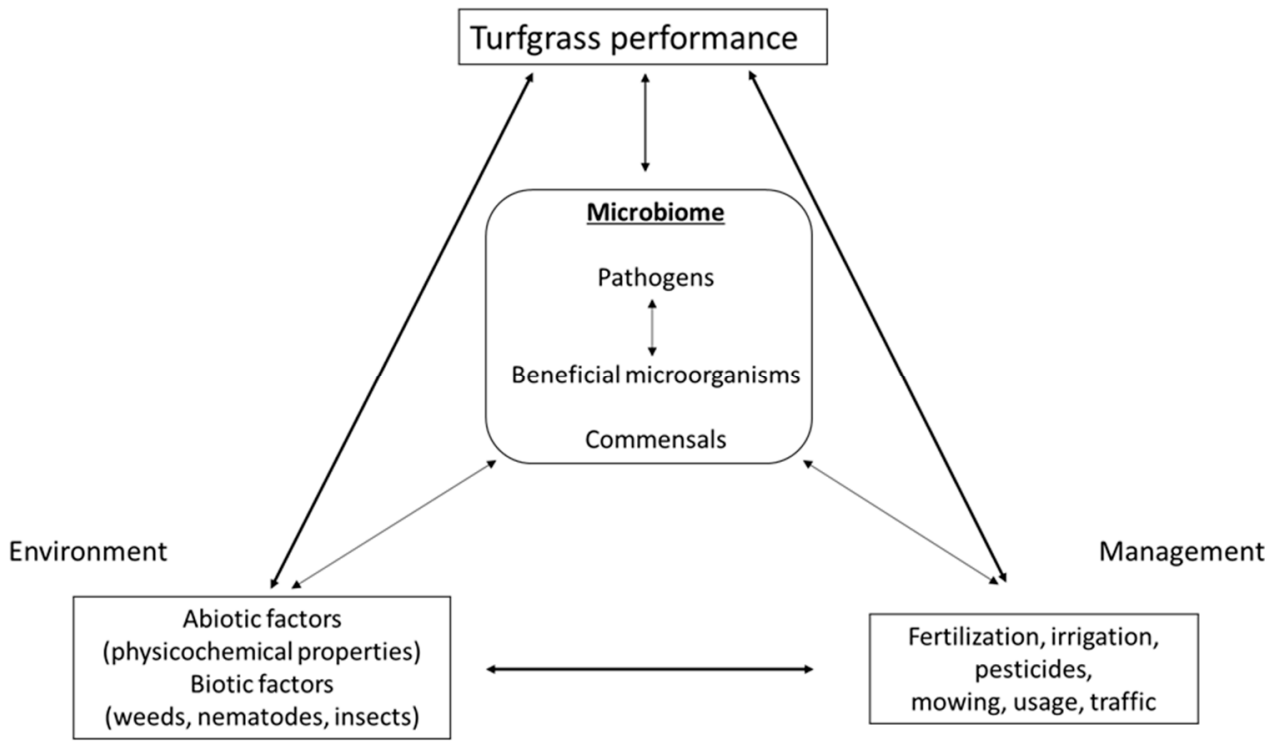

Figure 3. Interconnectedness of turfgrass management, environmental conditions, microbiome, and turfgrass performance. Connectors in bold indicate very strong support in the literature, whereas faint connectors indicate a critical lack of knowledge.

\section{Golf Course Management Changes Soil Properties}

Golf courses are among the most intensely managed ecosystems on this planet. Mowing, irrigation, fertilization, pesticide applications, aeration, traffic, and use of wetting agents impact physicochemical parameters that affect both grass performance as well as, presumably, microbiome composition and function. Some of these practices (e.g., mowing and irrigation) are carried out daily in the most highly managed golf areas like the greens and, therefore, may have a constant impact on the microbiome. Several studies show changes in soil properties in response to management practices on golf courses. A review of major changes in soil properties due to management practices commonly adopted by the golf industry can be found in Table 1 .

Table 1. Selected publications on the impact of common management practices in the golf industry on soil physicochemical properties and/or plant physiology.

\begin{tabular}{ccc}
\hline Management Practice & Impact on Soil Properties & References \\
\hline Mowing & $\begin{array}{c}\text { Reduces root density } \\
\text { Increases disease susceptibility } \\
\text { Change of nutrients } \\
\text { Change of soil pH } \\
\text { Changes soil chemistry } \\
\text { Irrigation }\end{array}$ & {$[56-58]$} \\
Pesticide applications & $\begin{array}{c}\text { Change of soil nutrient balance } \\
\text { Microbial community structure, enzyme } \\
\text { activities, soil invertebrate communities } \\
\text { Change in soil pH }\end{array}$ & {$[59-61]$} \\
Core aerification, dry injection & $\begin{array}{c}\text { Bulk density, surface hardness } \\
\text { Water content/infiltration }\end{array}$ & {$[64,65]$} \\
Verticutting & $\begin{array}{c}\text { Increases root weight and organic matter } \\
\text { concentration in soil }\end{array}$ & {$[66,67]$} \\
& $\begin{array}{c}\text { Improves soil water distribution through } \\
\text { the soil profile }\end{array}$ & {$[68]$} \\
Use of wetting agents & May enhance soil water content & {$[14,15,69-71]$} \\
& &
\end{tabular}

Similar to other plants, microbial communities associated with turfgrasses seem to differ significantly between the diverse niches on/in the plant. This might be partly due to management procedures that act differently in these habitats: e.g., we hypothesize that 
mowing has a stronger effect on phyllosphere organisms than on rhizosphere organisms and that irrigation or soil aeration has a higher impact on rhizosphere communities than on leaf communities. Similarly, even in the same 'compartments', physicochemical parameters most likely impact different members of the community in different ways, making it difficult or nearly impossible to predict responses of whole communities to different treatments. Based on the existing body of data, we speculate that, of all the microhabitats where plant-associated microbiota occurs, the endosphere of turfgrasses is the least impacted from the management effects and provides presumably the most stable niche. Therefore, it represents the ideal compartment for the inoculation of beneficial microbes. This is an important hypothesis that needs to be tested carefully. Additionally, constant mowing introduces 'wounds' and thus entry points to the endosphere for both pathogens and beneficial microbes. The fact that sharpening mower blades decrease the severity of plant diseases [56] is a clear indicator that these cuts are used by microorganisms to invade the plant tissue.

\section{Endosphere Microorganisms}

Endospheric microorganisms, which can either occur exclusively in the leaves or in the roots or colonize the entire plant, are highly diverse and different plants harbor distinct communities of bacteria and fungi in their tissue Rana [72]. In nearly all cases, exact in planta metabolism and thus their 'metabolic functions' are unknown. Hardoim et al. [73] defined endophytes as microorganisms that inhabit the tissue of plants, without assuming whether they might be pathogenic or beneficial to the host. The line between the two can be blurry and many organisms can be either pathogenic or beneficial, dependent on several abiotic and biotic factors [73-75]. In some cases, known pathogens and known beneficial organisms can colonize the same plant and provide an excellent system to study host-endophyte and endophyte-endophyte interactions [76]. Many grass species have been investigated for (fungal) endophytic microorganisms, but studies in golf turfgrass are rare. In switchgrass, it was shown that similar endosphere microorganisms can be recovered from different locations, while rhizosphere microbiota differed significantly [77], indicating a potential core-microbiome of the endosphere. Fungal endophytes have been reported from many different grass species and can increase forage quality, grass yield, and provide resistance to pests and weeds [78].

The best-known endophytes of cool-season grass species are among the fungal genus Epichloë, including E. festucae. Some Epichloë strains can produce antifungal proteins [79], and/or different kinds of alkaloids that can be effective against several fungi or even nematodes and insects [80-83]. While having desirable effects like restricting the growth of certain pathogens, these alkaloids can also cause fescue toxicosis in grassing cattle/ livestock [84-86]. The production of alkaloids that can diffuse through the plant tissue might explain that Epichloë can reduce root-knot nematode damage, although they are not even present in the roots. While biocontrol products using Epichloë are on the market, especially for grasses used for feedstock [87], their full potential has not been exploited [83-88]. To the best of our knowledge, Epichloë-enhanced grasses are not being used extensively in golf settings.

\section{Microbial Products for Turfgrasses}

Biological products consisting of both bacteria [89], as well as fungal strains [90], are being successfully used in many crops, especially products containing nitrogen-fixing bacteria that have a current market value of USD 1.5 billion [91]. Similarly, the agricultural biocontrol market in the US is highly valued, but still only contributes to around $3.5 \%$ of the global pesticide market [92]. On most golf courses, microbial products are usually not part of best management practices. There are certain limitations in order to develop endophytic fungi that produce exciting activities in a lab setting into a functioning commercially successful biocontrol product [93], but many of those can be overcome. The potential of mixed microbial communities to improve turfgrass health and performance 
has been demonstrated. Different soil treatments using organic material containing mixed microbial communities have shown efficacy to suppress different diseases in turfgrass. Among those, compost has been used very successfully [94-102]. While adding compost might have positive effects, results can be irreproducible due to its microbial and chemical diversity and complexity. In addition, plant and animal pathogens could also be a part of the compost [103] and can have negative effects on the turf. Therefore, we propose the use of single species as biocontrol agents rather than complex mixed communities. Unfortunately, so far, biocontrol agents are often unpredictable, and the results are too variable for commercial success [104]. Kenna and Snow [7] outlined the most important challenges that determine the success of novel biocontrol products for the golf industry: 1. Determine if the biocontrol agent readily establishes in the turf or surrounding areas;

2. Evaluate the effects of pesticides on the growth and development of the antagonist; 3. Estimate the likelihood of resistance to the effects of the biological agent; 4 . Reduce the need for conventional pesticides by providing an adequate level of control; 5 . Provide evidence that the biological agent is safe for people, wildlife, and the environment, and; 6. Develop methods for producing commercial quantities with an acceptable shelf life and cost. These challenges should guide the development of new microbial biocontrol products.

Biocontrol agents, including species of the bacterial genera Bacillus and Pseudomonas, and the fungal genus Trichoderma have been developed and are marketed for turfgrasses [23], but most of them address only very local problems with specific fungal pathogens. Nevertheless, the existing data clearly shows that biocontrol agents in agricultural settings can reduce the usage of fertilizers, reduce the need for insecticides and fungicides, and even reduce the need for herbicides [105]. Especially endophytic fungi have great potential to be developed into successful biocontrol agents in turfgrasses and in agriculture in general [106]. Other beneficial functions of the microbiome that are feasible to be developed, but have not really been explored in golf ecosystems, are the production of biosurfactants to replace or reduce the use of wetting agents [107] and increased resistance of the grasses to drought stress by microorganisms that can reduce water need of the plant [108].

\section{Conclusions}

A better understanding of the structure and function of turfgrass microbiomes and biotic and abiotic factors that shape them will lead to increased and more targeted usage of the microbiota to improve turfgrass performance on golf courses. Successful microbial products need to provide consistent and long-lasting effects, should be easy to apply and to store, cheap and easy to produce, be non-toxic for non-target organisms and the environment, and need to tolerate the intense management practices on golf courses. We assume that the addition of endophytic microorganisms has the greatest potential for biocontrol of pathogens and pests of turfgrasses. The endosphere provides a relatively stable environment and constant mowing introduces entry points that can be used for inoculation. Soil or rhizosphere bacteria might not establish long-lived populations, partly due to the management of turfgrasses that constantly alter physicochemical conditions in these habitats, and thus effects might be minimal. Additionally, endophytes of grasses have been described in great detail and, at least for some grass species, have produced nearly ideal biocontrol agents. Future studies need to fill the gap of knowledge on the structure and function of microbiomes of golf turf, establish culture collections of endophytes from different golf turfgrass species, and establish controlled experiments that test efficacy, longevity, and toxicity of potential biocontrol agents as well as their responses to common management practices on golf courses.

Funding: This research was partly funded by USDA/NIFA through HATCH project FLA-FTL-005631 to US.

Institutional Review Board Statement: Not applicable.

Informed Consent Statement: Not applicable. 
Data Availability Statement: Sequences used in Figure 2 were deposited in the SRA under SRR16988176-SRR16988223 (BioProject PRJNA781972).

Conflicts of Interest: The authors declare no conflict of interest. The funders had no role in the design of the study; in the collection, analyses, or interpretation of data; in the writing of the manuscript, or in the decision to publish the results.

\section{References}

1. Stackhouse, T.; Martinez-Espinoza, A.; Ali, M. Turfgrass disease diagnosis: Past, present, and future. Plants 2020, 9, 1544. [CrossRef] [PubMed]

2. Reedich, L.; Millican, M.; Koch, P. Temperature impacts on soil microbial communities and potential implications for the biodegradation of turfgrass pesticides. J. Environ. Qual. 2017, 46, 490-497. [CrossRef] [PubMed]

3. Wheeler, K.; Nauright, J. A global perspective on the environmental impact of golf. Sport Soc. 2006, 9, 427-443. [CrossRef]

4. Gelernter, W.D.; Stowell, L.J.; Johnson, M.E.; Brown, C.D. Documenting trends in land-use characteristics and environmental stewardship programs on us golf courses. Crop Forage Turfgrass Manag. 2017, 3, 1-12. [CrossRef]

5. Beard, J.; Green, R. The role of turfgrasses in environmental-protection and their benefits to humans. J. Environ. Qual. 1994, 23, 452-460. [CrossRef]

6. Gössling, S.; Hall, C.M.; Scott, D. Tourism and Water; Channel View Publications: Bristol, UK, 2015. [CrossRef]

7. Kenna, M.; Snow, J.; Clark, J. The us golf association turfgrass and environmental research program overview. Fate Manag. Turfgrass Chem. 2000, 743, 2-35.

8. Throssell, C.S.; Lyman, G.T.; Johnson, M.E.; Stacey, G.A.; Brown, C.D. Golf course environmental profile measures water use, source, cost, quality, management and conservation strategies. Appl. Turfgrass Sci. 2009, 6, 1-20. [CrossRef]

9. Gossling, S.; Peeters, P.; Hall, C.; Ceron, J.; Dubois, G.; Lehmann, L.; Scott, D. Tourism and water use: Supply, demand, and security. An international review. Tour. Manag. 2012, 33, 1-15. [CrossRef]

10. Li, Z.; Wang, G.; Zhang, K.; Gong, W.; Yu, E.; Tian, J.; Xie, J.; Yu, D. Epizootic ulcerative syndrome causes cutaneous dysbacteriosis in hybrid snakehead (channa maculata female $x$ channa argus male). PEERJ 2019, 7, e6674. [CrossRef]

11. Jespersen, D.; Schwartz, B. Drought avoidance traits in a collection of zoysiagrasses. Hortscience 2018, 53, 1579-1585. [CrossRef]

12. Jespersen, D.; Leclerc, M.; Zhang, G.; Raymer, P. Drought performance and physiological responses of bermudagrass and seashore paspalum. Crop Sci. 2019, 59, 778-786. [CrossRef]

13. Schwartz, B.; Hanna, W.; Baxter, L.; Raymer, P.; Waltz, F.; Kowalewski, A.; Chandra, A.; Genovesi, A.; Wherley, B.; Miller, G.; et al. 'dt-1', a drought-tolerant triploid turf bermudagrass. Hortscience 2018, 53, 1711-1714. [CrossRef]

14. Schiavon, M.; Leinauer, B.; Serena, M.; Maier, B.; Sallenave, R. Plant growth regulator and soil surfactants' effects on saline and deficit irrigated warm-season grasses: I. Turf quality and soil moisture. Crop Sci. 2014, 54, 2815-2826. [CrossRef]

15. Xiang, M.; Schiavon, M.; Orlinski, P.; Forconi, A.; Baird, J. Identification of wetting agents for water conservation on deficitirrigated hybrid bermudagrass fairways. Agron. J. 2021, 113, 3846-3856. [CrossRef]

16. Schiavon, M.; Baird, J. Evaluation of products to alleviate irrigation salinity stress on bermudagrass turf. Agron. J. 2018, 110, 2136-2141. [CrossRef]

17. Minoli, D.; Smith, M. An exploration of golf and voluntary environmental programmes. J. Environ. Plan. Manag. 2011, 54, 871-889. [CrossRef]

18. Knopper, L.; Lean, D. Carcinogenic and genotoxic potential of turf pesticides commonly used on golf courses. J. Toxicol. Environ. Health-Part B-Crit. Rev. 2004, 7, 267-279. [CrossRef]

19. Bekken, M.; Schimenti, C.; Soldat, D.; Rossi, F. A novel framework for estimating and analyzing pesticide risk on golf courses. Sci. Total Environ. 2021, 783, 146840. [CrossRef]

20. Petrovic, A. The fate of nitrogenous fertilizers applied to turfgrass. J. Environ. Qual. 1990, 19, 1-14. [CrossRef]

21. Platt, A.E. Toxic Green. Available online: https://www.thefreelibrary.com/Toxic+green\%3B+the+trouble+with+golf.-a015475523 (accessed on 12 February 2021).

22. European Parliamentary Research Service, E.P.R. Directive 2009/128/ec on the Sustainable Use of Pesticides. Available online: https:/ / www.europarl.europa.eu/RegData/etudes/STUD/2018/627113/EPRS_STU(2018)627113_EN.pdf (accessed on 12 February 2021).

23. Nelson, E.; Craft, C.; Clark, J.; Kenna, M. Microbial strategies for the biological control of turfgrass diseases. Fate Manag. Turfgrass Chem. 2000, 743, 342-352.

24. Jones, S. A snapshot of the microbiome field. Nat. Biotechnol. 2013, 31, 282-283. [CrossRef]

25. DunhamTrimmer Biocontrol Global Market Report. Available online: https://dunhamtrimmer.com/products/biocontrol-globalmarket-report/ (accessed on 12 February 2021).

26. Margulis, L.; Fester, R. Bellagio conference and book. Symbiosis as source of evolutionary innovation: Speciation and morphogenesis. Symbiosis 1991, 11, 93-101.

27. Bordenstein, S.R.; Theis, K.R. Host biology in light of the microbiome: Ten principles of holobionts and hologenomes. PLoS Biol. 2015, 13, e1002226. [CrossRef] [PubMed] 
28. Vandenkoornhuyse, P.; Quaiser, A.; Duhamel, M.; Le Van, A.; Dufresne, A. The importance of the microbiome of the plant holobiont. New Phytol. 2015, 206, 1196-1206. [CrossRef] [PubMed]

29. Sanchez-Canizares, C.; Jorrin, B.; Poole, P.; Tkacz, A. Understanding the holobiont: The interdependence of plants and their microbiome. Curr. Opin. Microbiol. 2017, 38, 188-196. [CrossRef]

30. Trivedi, P.; Leach, J.E.; Tringe, S.G.; Sa, T.; Singh, B.K. Plant-microbiome interactions: From community assembly to plant health. Nat. Rev. Microbiol. 2020, 18, 607-621. [CrossRef]

31. Berg, G.; Rybakova, D.; Fischer, D.; Cernava, T.; Verges, M.; Charles, T.; Chen, X.; Cocolin, L.; Eversole, K.; Corral, G.; et al. Microbiome definition re-visited: Old concepts and new challenges. Microbiome 2020, 8, 103. [CrossRef]

32. Thompson, L.R.; Sanders, J.G.; McDonald, D.; Amir, A.; Ladau, J.; Locey, K.J.; Prill, R.J.; Tripathi, A.; Gibbons, S.M.; Ackermann, G.; et al. A communal catalogue reveals earth's multiscale microbial diversity. Nature 2017, 551, 457-463. [CrossRef]

33. Rashid, M.; Stingl, U. Contemporary molecular tools in microbial ecology and their application to advancing biotechnology. Biotechnol. Adv. 2015, 33, 1755-1773. [CrossRef]

34. Kim, H.; Lee, Y. The rice microbiome: A model platform for crop holobiome. Phytobiomes J. 2020, 4, 5-18. [CrossRef]

35. Sharma, M.; Sudheer, S.; Usmani, Z.; Rani, R.; Gupta, P. Deciphering the omics of plant-microbe interaction: Perspectives and new insights. Curr. Genom. 2020, 21, 343-362. [CrossRef]

36. Xia, Q.; Rufty, T.; Shi, W. Predominant microbial colonizers in the root endosphere and rhizosphere of turfgrass systems: Pseudomonas veronii, Janthinobacterium lividum, and Pseudogymnoascus spp. Front. Microbiol. 2021, 12, 643904. [CrossRef]

37. Allan-Perkins, E.; Manter, D.; Jung, G. Soil microbial communities on roughs, fairways, and putting greens of cool-season golf courses. Crop Sci. 2019, 59, 1753-1767. [CrossRef]

38. Bartlett, M.; James, I.; Harris, J.; Ritz, K. Interactions between microbial community structure and the soil environment found on golf courses. Soil Biol. Biochem. 2007, 39, 1533-1541. [CrossRef]

39. Zhang, W.; Yao, T. Soil microbiota variation in perennial ryegrass turf and festuca elata turf using illumina sequencing. Res. J. Biotechnol. 2017, 12, 60-68.

40. Xia, Q.; Chen, H.; Yang, T.; Miller, G.; Shi, W. Defoliation management and grass growth habits modulated the soil microbial community of turfgrass systems. PLoS ONE 2019, 14, e0218967. [CrossRef] [PubMed]

41. Zhu, Y.; Ai, D.; Zhang, W. Difference of soil microbiota in perennial ryegrass turf before and after turning green using highthroughput sequencing technology. Res. J. Biotechnol. 2017, 12, 50-60.

42. Ban, L.; Li, J.; Yan, M.; Gao, Y.; Zhang, J.; Moural, T.; Zhu, F.; Wang, X. Illumina sequencing of 18s/16s rrna reveals microbial community composition, diversity, and potential pathogens in 17 turfgrass seeds. Plant Dis. 2021, 105, 1328-1338. [CrossRef]

43. Chen, Q.; Meyer, W.; Zhang, Q.; White, J. 16s rrna metagenomic analysis of the bacterial community associated with turf grass seeds from low moisture and high moisture climates. PEERJ 2020, 8, e8417. [CrossRef]

44. Koske, R.; Gemma, J.; Jackson, N. Mycorrhizal fungi associated with three species of turfgrass. Can. J. Bot. Rev. Can. Bot. 1997, 75, 320-332. [CrossRef]

45. Lundberg, D.; Lebeis, S.; Paredes, S.; Yourstone, S.; Gehring, J.; Malfatti, S.; Tremblay, J.; Engelbrektson, A.; Kunin, V.; del Rio, T.; et al. Defining the core arabidopsis thaliana root microbiome. Nature 2012, 488, 86-90. [CrossRef] [PubMed]

46. Bulgarelli, D.; Rott, M.; Schlaeppi, K.; van Themaat, E.; Ahmadinejad, N.; Assenza, F.; Rauf, P.; Huettel, B.; Reinhardt, R.; Schmelzer, E.; et al. Revealing structure and assembly cues for arabidopsis root-inhabiting bacterial microbiota. Nature 2012, 488, 91-95. [CrossRef]

47. Lemanceau, P.; Blouin, M.; Muller, D.; Moenne-Loccoz, Y. Let the core microbiota be functional. Trends Plant Sci. 2017, 22, 583-595. [CrossRef]

48. Pereira, E.; de Aldana, B.; San Emeterio, L.; Zabalgogeazcoa, I. A survey of culturable fungal endophytes from festuca rubra subsp. Pruinosa, a grass from marine cliffs, reveals a core microbiome. Front. Microbiol. 2019, 9, 3321. [CrossRef] [PubMed]

49. Agler, M.; Ruhe, J.; Kroll, S.; Morhenn, C.; Kim, S.; Weigel, D.; Kemen, E. Microbial hub taxa link host and abiotic factors to plant microbiome variation. PLoS Biol. 2016, 14, e1002352. [CrossRef]

50. Pangesti, N.; Pineda, A.; Hannula, S.; Bezemer, T. Soil inoculation alters the endosphere microbiome of chrysanthemum roots and leaves. Plant Soil 2020, 455, 107-119. [CrossRef]

51. Zhalnina, K.; Dias, R.; de Quadros, P.; Davis-Richardson, A.; Camargo, F.; Clark, I.; McGrath, S.; Hirsch, P.; Triplett, E. Soil ph determines microbial diversity and composition in the park grass experiment. Microb. Ecol. 2015, 69, 395-406. [CrossRef]

52. Wemheuer, B.; Thomas, T.; Wemheuer, F. Fungal endophyte communities of three agricultural important grass species differ in their response towards management regimes. Microorganisms 2019, 7, 37. [CrossRef] [PubMed]

53. Wemheuer, F.; Kaiser, K.; Karlovsky, P.; Daniel, R.; Vidal, S.; Wemheuer, B. Bacterial endophyte communities of three agricultural important grass species differ in their response towards management regimes. Sci. Rep. 2017, 7, 40914. [CrossRef]

54. Wemheuer, F.; Wemheuer, B.; Kretzschmar, D.; Pfeiffer, B.; Herzog, S.; Daniel, R.; Vidal, S. Impact of grassland management regimes on bacterial endophyte diversity differs with grass species. Lett. Appl. Microbiol. 2016, 62, 323-329. [CrossRef]

55. Diera, A.; Raymer, P.; Martinez-Espinoza, A.; Bauske, E.; Habteselassie, M. Evaluating the impact of turf-care products on soil biological health. J. Environ. Qual. 2020, 49, 858-868. [CrossRef] [PubMed]

56. Steinegger, D.; Shearman, R.; Riordan, T.; Kinbacher, E. Mower blade sharpness effects on turf. Agron. J. 1983, 75, 479-480. [CrossRef]

57. Beard, J.B. Turfgrass: Science and Culture; Prentice-Hall: Englewood Cliffs, NJ, USA, 1972. 
58. Juska, F.V.; Hanson, A.A. Effects of interval and height of mowing on growth of merion and common kentucky bluegrass (poa pratensis 1). Agron. J. 1961, 53, 385-388. [CrossRef]

59. Shaddox, T.; Unruh, J.; Kruse, J.; Restuccia, N. Solubility of iron, manganese, and magnesium sulfates and glucoheptonates in two alkaline soils. Soil Sci. Soc. Am. J. 2016, 80, 765-770. [CrossRef]

60. Shaddox, T.; Fu, H.; Gardner, D.; Goss, R.; Guertal, E.; Kreuser, W.; Miller, G.; Stewart, B.; Tang, K.; Unruh, J. Solubility of ten iron fertilizers in eleven north american soils. Agron. J. 2019, 111, 1498-1505. [CrossRef]

61. Thompson, D.; Clarke, B.; Heckman, J. Nitrogen form and rate of nitrogen and chloride application for the control of summer patch in kentucky bluegrass. Plant Dis. 1995, 79, 51-56. [CrossRef]

62. Serena, M.; Leinauer, B.; Schiavon, M.; Maier, B.; Sallenave, R. Establishment and rooting response of bermudagrass propagated with saline water and subsurface irrigation. Crop Sci. 2014, 54, 827-836. [CrossRef]

63. Schiavon, M.; Leinauer, B.; Serena, M.; Sallenave, R.; Maier, B. Bermudagrass and seashore paspalum establishment from seed using differing irrigation methods and water qualities. Agron. J. 2012, 104, 706-714. [CrossRef]

64. Gan, H.; Wickings, K. Soil ecological responses to pest management in golf turf vary with management intensity, pesticide identity, and application program. Agric. Ecosyst. Environ. 2017, 246, 66-77. [CrossRef]

65. Smiley, R.; Craven, M. Fungicides in kentucky bluegrass turf-Effects on thatch and pH. Agron. J. 1978, 70, 1013-1019. [CrossRef]

66. Atkinson, J.; McCarty, L.; Bridges, W. Effect of core aerification frequency, area impacted, and topdressing rate on turf quality and soil physical properties. Agron. J. 2012, 104, 1710-1715. [CrossRef]

67. Craft, J.; Baldwin, C.; Philley, W.; McCurdy, J.; Stewart, B.; Tomaso-Peterson, M.; Blythe, E. Impact of dry-injection cultivation to maintain soil physical properties for an ultradwarf bermudagrass putting green. Hortscience 2016, 51, 1171-1175. [CrossRef]

68. Rowland, J.; Cisar, J.; Snyder, G.; Sartain, J.; Wright, A. Usga ultradwarf bermudagrass putting green properties as affected by cultural practices. Agron. J. 2009, 101, 1565-1572. [CrossRef]

69. Serena, M.; Schiavon, M.; Sallenave, R.; Leinauer, B. Drought avoidance of warm-season turfgrasses affected by irrigation system, soil surfactant revolution, and plant growth regulator trinexapac-ethyl. Crop Sci. 2020, 60, 485-498. [CrossRef]

70. Serena, M.; Schiavon, M.; Sallenave, R.; Leinauer, B. Nitrogen fertilization of warm-season turfgrasses irrigated with saline water from varying irrigation systems. 1. Quality, spring green-up and fall colour retention. J. Agron. Crop Sci. 2018, 204, 252-264. [CrossRef]

71. Schiavon, M.; Orlinski, P.; Petelewicz, P.; Pudzianowska, M.; Baird, J. Effects of trinexapac-ethyl, surfactant, and nitrogen fertilization on bermudagrass water use. Agron. J. 2019, 111, 3057-3066. [CrossRef]

72. Rana, K.; Kour, D.; Kaur, T.; Devi, R.; Yadav, A.; Yadav, N.; Dhaliwal, H.; Saxena, A. Endophytic microbes: Biodiversity, plant growth-promoting mechanisms and potential applications for agricultural sustainability. Antonie Van Leeuwenhoek Int. J. Gen. Mol. Microbiol. 2020, 113, 1075-1107. [CrossRef] [PubMed]

73. Hardoim, P.; van Overbeek, L.; Berg, G.; Pirttila, A.; Compant, S.; Campisano, A.; Doring, M.; Sessitsch, A. The hidden world within plants: Ecological and evolutionary considerations for defining functioning of microbial endophytes. Microbiol. Mol. Biol. Rev. 2015, 79, 293-320. [CrossRef]

74. Bacon, C.; Glenn, A.; Yates, I. Fusarium verticillioides: Managing the endophytic association with maize for reduced fumonisins accumulation. Toxin Rev. 2008, 27, 411-446. [CrossRef]

75. Brader, G.; Compant, S.; Vescio, K.; Mitter, B.; Trognitz, F.; Ma, L.; Sessitsch, A.; Leach, J.; Lindow, S. Ecology and genomic insights into plant-pathogenic and plant-nonpathogenic endophytes. Annu. Rev. Phytopathol. 2017, 55, 61-83. [CrossRef] [PubMed]

76. Estrada, A.; Jonkers, W.; Kistler, H.; May, G. Interactions between Fusarium verticillioides, Ustilago maydis, and Zea mays: An endophyte, a pathogen, and their shared plant host. Fungal Genet. Biol. 2012, 49, 578-587. [CrossRef]

77. Singer, E.; Bonnette, J.; Woyke, T.; Juenger, T. Conservation of endophyte bacterial community structure across two panicum grass species. Front. Microbiol. 2019, 10, 2181. [CrossRef] [PubMed]

78. Gundel, P.; Perez, L.; Helander, M.; Saikkonen, K. Symbiotically modified organisms: Nontoxic fungal endophytes in grasses. Trends Plant Sci. 2013, 18, 425-432. [CrossRef]

79. Tian, Z.; Wang, R.; Clarke, B.; Belanger, F. An epichole festucae endophyte antifungal protein with activity against the dollar spot pathogen. Phytopathology 2017, 107, 12.

80. Schardl, C.; Leuchtmann, A.; Spiering, M. Symbioses of grasses with seedborne fungal endophytes. Annu. Rev. Plant Biol. 2004, 55, 315-340. [CrossRef]

81. Xia, C.; Li, N.; Zhang, Y.; Li, C.; Zhang, X.; Nan, Z. Role of epichloe endophytes in defense responses of cool-season grasses to pathogens: A review. Plant Dis. 2018, 102, 2061-2073. [CrossRef] [PubMed]

82. Saikkonen, K.; Gundel, P.; Helander, M. Chemical ecology mediated by fungal endophytes in grasses. J. Chem. Ecol. 2013, 39, 962-968. [CrossRef] [PubMed]

83. Card, S.; Bastias, D.; Caradus, J. Antagonism to plant pathogens by epichloe fungal endophytes-A review. Plants 2021, 10, 1997. [CrossRef] [PubMed]

84. Kallenbach, R. Bill e. Kunkle interdisciplinary beef symposium: Coping with tall fescue toxicosis: Solutions and realities. J. Anim. Sci. 2015, 93, 5487-5495. [CrossRef] [PubMed]

85. Poole, R.; Brown, A.; Poore, M.; Pickworth, C.; Poole, D. Effects of endophyte-infected tall fescue seed and protein supplementation on stocker steers: Ii. Adaptive and innate immune function. J. Anim. Sci. 2019, 97, 4160-4170. [CrossRef] [PubMed] 
86. Poole, R.; Womble, C.; Poore, M.; Poole, D.; Pickworth, C. Effects of endophyte-infected tall fescue seed and protein supplementation on stocker steers: I. Growth performance and hemodynamic responses. J. Anim. Sci. 2019, 97, 3776-3785. [CrossRef] [PubMed]

87. Kauppinen, M.; Saikkonen, K.; Helander, M.; Pirttila, A.; Wali, P. Epichloe grass endophytes in sustainable agriculture. Nat. Plants 2016, 2, 15224. [CrossRef] [PubMed]

88. Caradus, J.; Johnson, L. Epichloe fungal endophytes-from a biological curiosity in wild grasses to an essential component of resilient high performing ryegrass and fescue pastures. J. Fungi 2020, 6, 322. [CrossRef] [PubMed]

89. Compant, S.; Clement, C.; Sessitsch, A. Plant growth-promoting bacteria in the rhizo- and endosphere of plants: Their role, colonization, mechanisms involved and prospects for utilization. Soil Biol. Biochem. 2010, 42, 669-678. [CrossRef]

90. Bamisile, B.S.; Akutse, K.S.; Siddiqui, J.A.; Xu, Y. Model application of entomopathogenic fungi as alternatives to chemical pesticides: Prospects, challenges, and insights for next-generation sustainable agriculture. Front. Plant Sci. 2021, 12, 741804. [CrossRef]

91. Batista, B.; Singh, B. Realities and hopes in the application of microbial tools in agriculture. Microb. Biotechnol. 2021, 14, 1258-1268. [CrossRef]

92. Parnell, J.; Berka, R.; Young, H.; Sturino, J.; Kang, Y.; Barnhart, D.; DiLeo, M. From the lab to the farm: An industrial perspective of plant beneficial microorganisms. Front. Plant Sci. 2016, 7, 1110. [CrossRef]

93. Bamisile, B.S.; Siddiqui, J.A.; Akutse, K.S.; Ramos Aguila, L.C.; Xu, Y. General limitations to endophytic entomopathogenic fungi use as plant growth promoters, pests and pathogens biocontrol agents. Plants 2021, 10, 2119. [CrossRef] [PubMed]

94. Aamlid, T.; Espevig, T.; Tronsmo, A. Microbiological products for control of microdochium nivale on golf greens. Crop Sci. 2017, 57, 559-566. [CrossRef]

95. Aamlid, T.; Andersen, T.; Kvalbein, A.; Pettersen, T.; Jensen, A. Composted garden waste as organic amendment to the usgarootzone and topdressing sand on red fescue (Festuca rubra) greens. Eur. J. Hortic. Sci. 2014, 79, 87-96.

96. Azeem, M.; Hale, L.; Montgomery, J.; Crowley, D.; McGiffen, M. Biochar and compost effects on soil microbial communities and nitrogen induced respiration in turfgrass soils. PLOS ONE 2020, 15, e0242209. [CrossRef]

97. Boulter, J.; Boland, G.; Trevors, J. Assessment of compost for suppression of fusarium patch (microdochium nivale) and typhula blight (Typhula ishikariensis) snow molds of turfgrass. Biol. Control 2002, 25, 162-172. [CrossRef]

98. Boulter, J.; Boland, G.; Trevors, J. Evaluation of composts for suppression of dollar spot (Sclerotinia homoeocarpa) of turfgrass. Plant Dis. 2002, 86, 405-410. [CrossRef]

99. Boulter, J.; Trevors, J.; Boland, G. Microbial studies of compost: Bacterial identification, and their potential for turfgrass pathogen suppression. World J. Microbiol. Biotechnol. 2002, 18, 661-671. [CrossRef]

100. Boulter, J.; Boland, G.; Trevors, J. Compost: A study of the development process and end-product potential for suppression of turfgrass disease. World J. Microbiol. Biotechnol. 2000, 16, 115-134. [CrossRef]

101. Coelho, L.; Reis, M.; Guerrero, C.; Dionisio, L. Use of organic composts to suppress bentgrass diseases in agrostis stolonifera. Biol. Control 2020, 141, 104154. [CrossRef]

102. Stacey, N.; Lewis, R.; Davenport, J.; Sullivan, T. Composted biosolids for golf course turfgrass management: Impacts on the soil microbiome and nutrient cycling. Appl. Soil Ecol. 2019, 144, 31-41. [CrossRef]

103. Noble, R. Risks and benefits of soil amendment with composts in relation to plant pathogens. Australas. Plant Pathol. 2011, 40, 157-167. [CrossRef]

104. Meyer, S.L. United states department of agriculture-agricultural research service research programs on microbes for management of plant-parasitic nematodes. Pest Manag. Sci. 2003, 59, 665-670. [CrossRef]

105. Harding, D.P.; Raizada, M.N. Controlling weeds with fungi, bacteria and viruses: A review. Front. Plant Sci. 2015, 6, 659. [CrossRef]

106. Pozo, M.; Zabalgogeazcoa, I.; de Aldana, B.; Martinez-Medina, A. Untapping the potential of plant mycobiomes for applications in agriculture. Curr. Opin. Plant Biol. 2021, 60, 102034. [CrossRef] [PubMed]

107. Nitschke, M.; Silva, S.S.E. Recent food applications of microbial surfactants. Crit. Rev. Food Sci. Nutr. 2018, 58, 631-638. [CrossRef] [PubMed]

108. Kannadan, S.; Rudgers, J. Endophyte symbiosis benefits a rare grass under low water availability. Funct. Ecol. 2008, 22, 706-713. [CrossRef] 